\title{
The Creatine Kinase/Creatine Connection to Alzheimer's Disease: CK Inactivation, APP-CK Complexes, and Focal Creatine Deposits
}

\author{
Tanja S. Bürklen, ${ }^{1}$ Uwe Schlattner, ${ }^{1,2}$ Ramin Homayouni, ${ }^{3}$ Kathleen Gough, ${ }^{4}$ Margaret Rak, ${ }^{4}$ \\ Adriana Szeghalmi, ${ }^{4}$ and Theo Wallimann ${ }^{1}$ \\ ${ }^{1}$ Institute of Cell Biology, ETH Zurich, Hönggerberg HPM, 8093 Zurich, Switzerland \\ ${ }^{2}$ Laboratory of Fundamental and Applied Bioenergetics, INSERM E0221, Joseph Fourier University, 38041 Grenoble, Cedex 9 , France \\ ${ }^{3}$ Department of Neurology, University of Tennessee Health Science Center, Memphis, TN 38163, USA \\ ${ }^{4}$ Department of Chemistry, University of Manitoba, Winnipeg, Manitoba, Canada R3T 2N2
}

Received 12 December 2005; Revised 28 February 2006; Accepted 28 February 2006

Cytosolic brain-type creatine kinase (BB-CK), which is coexpressed with ubiquitous mitochondrial uMtCK, is significantly inactivated by oxidation in Alzheimer's disease (AD) patients. Since CK has been shown to play a fundamental role in cellular energetics of the brain, any disturbance of this enzyme may exasperate the AD disease process. Mutations in amyloid precursor protein (APP) are associated with early onset $\mathrm{AD}$ and result in abnormal processing of APP, and accumulation of $\mathrm{A} \beta$ peptide, the main constituent of amyloid plaques in AD brain. Recent data on a direct interaction between APP and the precursor of uMtCK support an emerging relationship between $\mathrm{AD}$, cellular energy levels, and mitochondrial function. In addition, recently discovered creatine (Cr) deposits in the brain of transgenic AD mice, as well as in the hippocampus from AD patients, indicate a direct link between perturbed energy state, $\mathrm{Cr}$ metabolism, and $\mathrm{AD}$. Here, we review the roles of $\mathrm{Cr}$ and $\mathrm{Cr}$-related enzymes and consider the potential value of supplementation with $\mathrm{Cr}$, a potent neuroprotective substance. As a hypothesis, we consider whether $\mathrm{Cr}$, if given at an early time point of the disease, may prevent or delay the course of $\mathrm{AD}$-related neurodegeneration.

Copyright (C) 2006 Tanja S. Bürklen et al. This is an open access article distributed under the Creative Commons Attribution License, which permits unrestricted use, distribution, and reproduction in any medium, provided the original work is properly cited.

\section{FUNCTION AND SUBCELLULAR LOCALIZATION OF THE CREATINE KINASE ISOENZYME FAMILY MEMBERS IN BRAIN}

Large amounts of energy are required to maintain the signalling activities of the cells in the central nervous system (CNS). The dominant share of energy consumption in the brain can be assigned to brain function-related processes, for example, for maintenance of membrane potential by the $\mathrm{Na}^{+} / \mathrm{K}^{+}$-ATPase, $\mathrm{Ca}^{2+}$ homeostasis by the $\mathrm{Ca}^{2+}$-ATPase, neurotransmitter processing, intracellular signalling, and axonal as well as dendritic transport [1]. Mechanisms to facilitate energy transfer within cells that require fluctuating high energy levels, such as those in skeletal muscle, heart, and brain, include the juxtaposition of intracellular sites of ATP generation with sites of ATP consumption, as well as the transfer of high-energy phosphates between these sites by the creatine kinase (CK)/phosphocreatine (PCr) system $[1,2]$.
CK is categorized into four isoforms based on its tissue expression (muscle or brain) and subcellular distribution (cytosolic or mitochondrial). In sarcomeric muscle, dimeric cytosolic muscle-type CK (MM-CK) is localized to the Mband [3], the sarcoplasmic reticulum (SR) $[4,5]$, and the plasma membrane. At these sites, MM-CK is functionally coupled to the myofibrillar acto-myosin ATPase [6-8], the SR $\mathrm{Ca}^{2+}$-ATPase $[4,5]$, and the plasma membrane $\mathrm{Na}^{+} / \mathrm{K}^{+}$ ATPase [9], respectively, and utilizes PCr for local in situ regeneration of ATP. In the brain, the dimeric cytosolic form of CK is called brain-type CK (BB-CK). The octameric mitochondrial CK (MtCK) is classified into two forms: sarcomeric muscle form (sMtCK) and brain form called ubiquitous MtCK (uMtCK) [10, 11]. Both MtCKs are located in the mitochondrial intermembrane space [12], along the entire inner membrane and also at peripheral contact sites [13], where inner and outer membranes are in close proximity $[14,15]$. There, MtCK can directly transphosphorylate 


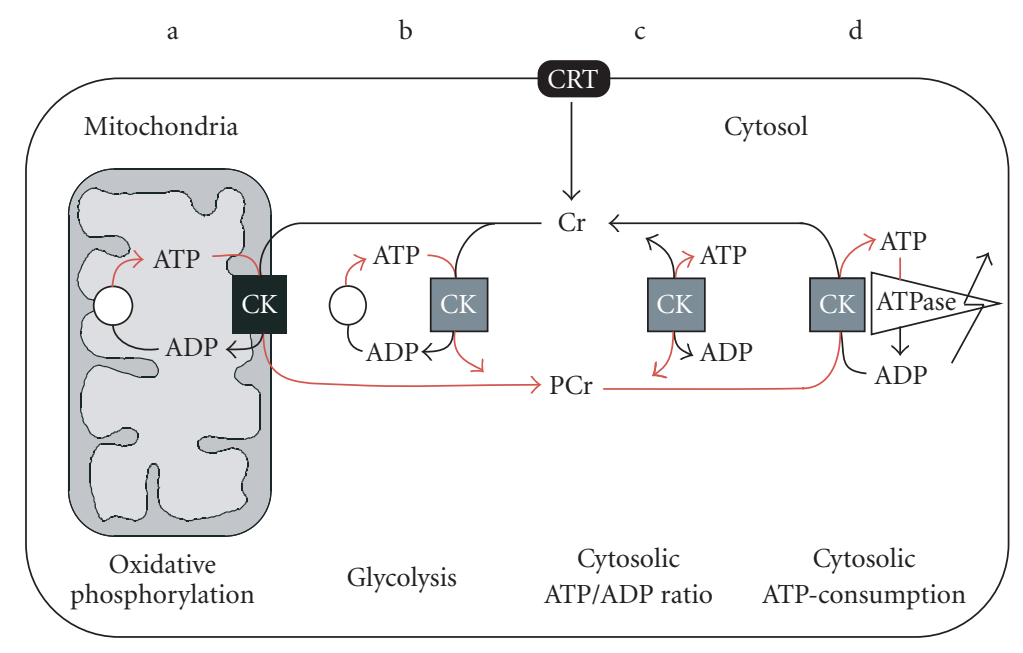

Figure 1: The CK/PCr system.

intramitochondrially produced ATP into PCr [16], which is then exported into the cytosol.

$\mathrm{uMtCK}$ is always coexpressed with dimeric cytosolic BBCK [17] at various levels throughout the entire brain. In cerebellum, both of these CK isoforms are found highly concentrated in the glomeruli structures of the cerebellar granular layer. However, the level of BB-CK is much higher than uMtCK in cerebellar Bergmann glial cells. In addition, both isoforms are highly expressed in the choroid plexus and in hippocampal granule and pyramidal cells. The hippocampus is important for learning and memory and is most severely affected in $\mathrm{AD}[18]$.

Generation of ATP, hence CK activity, is critical for CNS function. Neurons require a great amount of ATP to maintain membrane polarization, $\mathrm{Ca}^{2+}$ influx from organelles, processing of neurotransmitters, intracellular signalling systems, and axonal and dendritic transport [1]. Interestingly, $\mathrm{CK}$ is specifically associated with these important processes. On a subcellular level, BB-CK has been found in association with synaptic vesicles [19] and synaptic plasma membranes [20]. On the other hand, supporting glial cells also require ATP for neurotransmitter uptake. In the rat hypothalamus, BB-CK plays an essential role in regenerating ATP for glutamate clearance during excitatory synaptic transmission [21]. Therefore, the number of synapses and synaptic plasticity can be profoundly regulated by ATP levels in neuronal and nonneuronal cells [22].

During brain development, there is a coincidence in the timing of maximal expression of BB-CK and myelin basic protein in the cerebellum which is an indication for a role of BB-CK in myelination [23]. Both BB-CK and uMtCK levels are increased in a coordinated fashion during postnatal brain development [24]. In brain, CK has been shown to be associated with synaptic membranes [25] and to facilitate glutamate uptake into vesicles [26], thus being directly involved in the energetics of neurotransmitter uptake. CK has also been shown to be associated with acetylcholine receptor-rich membranes [27] and to be involved in quantal release of acetylcholine in synaptosomes [28]. Further, CK together with enolase are part of a complex which is involved in axonal transport [29] and thus support the energetics of these transport events. CK has also been shown to be functionally coupled to the $\mathrm{Na}^{+}-\mathrm{K}^{+}$ATPase $[9,30]$, as well as to the ATP-gated $\mathrm{K}^{+}$-channel $[31,32]$. This seems to be important due to the fact that about $50 \%$ of total brain energy is used by the $\mathrm{Na}^{+}$ion pump [1]. In addition, CK knock-out mice display a significant neurological phenotype $[33,34]$. Based on these findings, a functional CK/PCr energy shuttle system has been proposed [35], where BB-CK and uMtCK would constitute an efficient energy buffering and shuttle system in brain [36], similar to that observed in muscle.

\section{THE CREATINE KINASE/PHOSPHOCREATINE SHUTTLE SYSTEM IN THE BRAIN}

As mentioned above, the major energy-consuming process in neural cells is the transport of ions by the $\mathrm{Na}^{+} / \mathrm{K}^{+}$-ATPase [37]. Even though the cellular pools of ATP are rather small and the movement of ATP within cells by diffusion is slow [1], no significant change in overall ATP levels can be detected during activation of excitable tissues [38]. This is because ATP is continuously and efficiently replenished from the large pools of PCr through the CK reaction, as has been shown in detail in muscle cells [39-42]. The CK isoenzymes catalyze the reversible transfer of the high-energy $\mathrm{N}$ phosphoryl group of phosphocreatine ( $\mathrm{PCr}$ ) to ADP to yield ATP. The concept of the creatine kinase/phosphocreatine (CK/PCr) shuttle system (Figure 1) describes the functional association of CK isoenzymes with discrete intracellular compartments at sites of ATP production and utilization. Thus, $\mathrm{PCr}$ and $\mathrm{Cr}$ serve as cytosolic energy transducers to connect these intracellular sites and together with precisely localized CK isoenzymes constitute an organizational feature that increases the efficiency of energy metabolism $[1,39,41]$. 
The CK/PCr system functions as a temporal and spatial energy buffer, as well as a regulator of cellular energetics $[39,42,43]$. It maintains high global ATP/ADP ratios by preventing a rise in intracellular free ADP and thus preserves the thermodynamic efficiency of ATPases even at high cellular ATP turnover [36]. By this mechanism, an inactivation of cellular ATPases by rising [ADP] is avoided and a net loss of adenine nucleotides is prevented $[39,44,45]$. Thus, the $\mathrm{CK} / \mathrm{PCr}$ system is a rapidly available source for ATP transport and resynthesis not only in muscle but also in the brain. The high activity of CK in the brain, together with high concentrations of its substrates, $\mathrm{PCr}$ and $\mathrm{Cr}$, as well as the phenotype of mice deficient in brain-type CK isoforms [34, 35] and the effects of $\mathrm{Cr}$ supplementation on brain function (see below) strongly indicate that $\mathrm{CK}$ is a key enzyme in brain energy metabolism [46] and that PCr is an important energy reservoir and energy transport molecule [47]. A schematic drawing of the subcellular micro-compartmentation of CK enzymes and their colocalization with ATP-producing and consuming sites within the cell is depicted in Figure 1 (from Schlattner U and Wallimann T. Metabolite channeling: creatine kinase micro compartments, to (Lennarz WJ, and Lane MD, eds.) Encyclopedia of Biological Chemistry. Vol 2. New York, USA: Academic Press; (2004):646-651; with permission by ELSEVIER Publishing Company).

Isoenzymes of $\mathrm{CK}$ are found in different compartments such as mitochondria (a) and the cytosol (b)-(d) in a soluble form (c) or associated to a different degree to ATP-delivering processes, for example, mitochondrial oxidative phosphorylation (a) or glycolysis (b) or to ATP-consuming processes, like ATPases or other ATP-requiring or ATP-regulated processes (d). A large cytosolic PCr pool up to $30 \mathrm{mM}$ is built up by CK using ATP generated by oxidative phosphorylation (a) or glycolysis (b). PCr is then used to buffer global (c) and local (d) ATP/ADP ratios. In cells that are polarized and/or have a very high or localized ATP consumption, these CK isoenzymes, together with easily diffusible $\mathrm{PCr}$, also maintain an energy shuttle between ATP-providing and ATP-consuming processes (a), (d). Metabolite channeling occurs where CK is associated with ATP-providing or ATP-consuming transporters, ion pumps, or enzymes that are operating also in brain (a), (d). Cr is synthesized mostly in kidney and liver. Cells can take up Cr from the blood stream by a specific creatine transporter CRT. In brain, CRT is prominently localized at the blood-brain barrier, but is also seen on the plasma membrane of neurons [48-51].

Details on the importance of CK and its substrates for brain function are revealed by recent studies on the neurological and behavior phenotype of CK knockout mice $[33,34]$. Mice lacking the expression of one CK isoform, cytosolic BB-CK or uMtCK, display abnormalities in formation and maintenance of hippocampal mossy fibre connections and in behaviors such as habituation, spatial learning, and seizure susceptibility [34]. On the other hand, adult mice lacking both BB-CK and uMtCK, the so-called CK double knockout mice, display reduced body weight and are severely impaired in spatial learning in both dry and wet maze, and display lower nest building activity and acoustic startle reflex responses [34]. Morphological analysis of CK double knockout brains revealed a reduction of brain weight and hippocampal size, a smaller regio-inferior area, and relatively larger supra-pyramidal and intra-infra-pyramidal mossy fiber area [34]. These results suggest that the lack of both brain-specific CK isoforms renders the synaptic circuitry less efficient in coping with sensory or cognitive activity related challenges in the adult brain and fully support the physiological importance of CK for normal brain function.

\section{CREATINE SYNTHESIS AND UPTAKE IN BRAIN}

In vertebrates, $\mathrm{Cr}$ is synthesized mostly in the liver and kidney and is then transported through the blood and taken up by target tissues with high energy demands. Cr biosynthesis involves two sequential steps catalyzed by L-arginine: glycine amidinotransferase (AGAT) and S-adenosylmethionine:guanidinoacetate $\mathrm{N}$-methyltransferase (GAMT) [51]. It has been shown that a certain amount of $\mathrm{Cr}$ is synthesized endogenously in the developing brain [51-53], and recently both AGAT and GAMT, as well as creatine transporter (CRT) have been identified and localized in distinct cell populations of the developing brain [51, 52]. GAMT immunoreactivity is very strong in oligodendrocytes, moderate in astrocytes, and not detected in embryonic neurons. These observations led to the conclusion that $\mathrm{Cr}$ in neurons is derived in part from local glial populations surrounding the neurons, indicating a novel neuron-glial relationship involving $\mathrm{Cr}$ trafficking [49]. However, the majority of $\mathrm{Cr}$ seems to get taken up continuously through the blood-brain barrier by CRT [48], which works against a huge $\mathrm{Cr}$ gradient [54]. Nevertheless, certain brain cells seem to have the capacity for endogenous $\mathrm{Cr}$ biosynthesis, especially in the developing brain [51]. Patients with genetic CRT-deficiency lack any detectable $\mathrm{Cr}$ in the brain [55] and have severe neurological phenotypes including hypotonia, developmental speech delay, autism, and brain atrophy $[55,56]$. These cases emphasize the importance of the substrates of $\mathrm{CK}, \mathrm{Cr}$, and PCr, for normal brain function in man.

\section{DISTURBED ENERGY METABOLISM IN NEURODEGENERATIVE DISEASES}

A common feature of severe neurodegenerative disorders, such as Huntington's disease (HD), Amyotrophic lateral sclerosis (ALS), Parkinson's disease (PD), and AD are mutations in nuclear or mitochondrial DNA. This leads to secondary mitochondrial dysfunction accompanied by a more or less severely disturbed energy metabolism as well as a disturbed energetic status of the brain [57]. Cellular energy reserves are important for normal brain function, however, the cellular energy state also appears to play a key role in regulating and initiating apoptosis or necrosis of brain cells, since mitochondria are known to be essential in controlling specific apoptotic pathways [58]. For example, in patients with ALS, a chronically deficient intake of energy [59], increased mitochondrial volume (swelling), oxidative damage, and decreased complex I activity have been observed [60]. Further, 
a loss of mitochondrial membrane potential and chronically elevated cytosolic $\mathrm{Ca}^{2+}$-levels accompany these observations [61].

One of the most important hallmarks in the pathogenesis of senile dementia of the Alzheimer type (AD) is the marked decrease of cerebral glucose metabolism [62] caused by disturbed acetyl-CoA synthesis and critically lowered oxidative phosphorylation [63]. Measurement of local cerebral glucose metabolism by positron emission tomography (PET) has become a standard technique to study dementia [64]. By this method, a regional impairment of cerebral glucose metabolism in neocortical association areas in the brains of AD patients could be shown [64]. In addition, cortical acetylcholine esterase activity is significantly lower in patients with $\mathrm{AD}$ compared to age-matched normal controls [64]. A decrease of the oxidative energy metabolism in senile dementia and the resulting ATP deficit may thus change protein degradation, synaptic transmission and ion homeostasis [63]. Furthermore, disturbed function and abnormal morphology of mitochondria are also associated with $\mathrm{AD}$ and PD [65].

A global decrease in cerebral metabolic rate also occurs in $\mathrm{AD}$ and in other dementias, and the $\mathrm{AD}$ brain is characterized by a variable, but often marked, loss of neurons, a deposition of extracellular plaques, and intracellular neurofibrillary tangles [66-68]. Impaired energy metabolism [68] and altered cytochrome $\mathrm{c}$ oxidase activity are among the earliest detectable defects in AD [69-72]. Most recently, focal deposits of $\mathrm{Cr}$ have been discovered in $\mathrm{AD}$ [73], suggestive of a perturbed energetic status and deregulated $\mathrm{Cr}$ synthesis and/or uptake (see further below).

\section{MITOCHONDRIAL ASPECTS OF NEURODEGENERATION}

The involvement of mitochondria in neurological disorders is frequently discussed. It is known that pathological states and mitochondrial dysfunction often lead to the excessive generation of free radicals and subsequent oxidative damage [74]. Studies of AD patients have identified decreased complex IV activity and mitochondrial DNA mutations $[75,76]$. Recently, a role for mitochondria has been indicated in $\mathrm{A} \beta$ induced apoptosis. The $\mathrm{A} \beta$-binding alcohol dehydrogenase (ABAD) has been reported to interact with $\mathrm{A} \beta$ in the mitochondria of $\mathrm{AD}$ patients and transgenic mice [77] and to potentiate $\mathrm{A} \beta$-induced apoptosis and free-radical generation in neurons. Furthermore, in brains from patients with autopsy-confirmed $\mathrm{AD}$ and clinical dementia ratings before death, the activity of tricarboxylic acid cycle (TCA) enzymes (pyruvate dehydrogenase complex, isocitrate dehydrogenase, and the alpha-ketoglutarate dehydrogenase) of mitochondria were significantly decreased. Changes in TCA cycle activities correlated with the clinical state of the disease, suggesting a coordinated mitochondrial alteration [77]. Recently, a structural and functional interplay between dendritic mitochondria and spines/synapses was discovered in in vitro cultured neurons [78]. A small fraction of mitochondria is present within dendritic protrusions of cultured neurons [78]. Interestingly, in these cultured neurons, $\mathrm{Cr}$ supplementation enhances mitochondrial activity and causes a higher density of spines and synapses. Remarkably, the ability of neurons to form new excitatory synapses in response to stimulation is also correlated with increased activity of dendritic mitochondria [78]. Neuronal activity itself affects the motility, fusion/fission balance, and subcellular distribution of mitochondria in dendrites, depending on calcium influx. This seems to be physiologically relevant, because repetitive depolarization that stimulates synapse formation causes the redistribution of mitochondria into dendritic protrusions [78]. These results suggest a local involvement of mitochondria in synapse formation and development. Taken together, these findings are in agreement with the concept that the characteristic loss of synapses in disorders like $\mathrm{AD}$ arises in part from mitochondrial dysfunction [79].

\section{PERTURBED CK FUNCTIONS AND LOWER PCR/CR RATIOS ARE LINKED TO NEURODEGENERATIVE DISEASES INCLUDING AD}

Oxidative alterations of proteins and lipids have been implicated in the progression of neurodegenerative disorders $[80,81]$. Protein carbonyls, considered a marker of protein oxidation, are increased in $\mathrm{AD}$ [82]. Using a proteomic approach, BB-CK, glutamine synthase (GS), and ubiquitin carboxy-terminal hydrolase 1-1 (UCH L-1) were identified as the three major specifically oxidized proteins in AD brains [83]. Oxidative modification of CK rapidly inactivates the enzyme and results in abnormal partitioning of CK between the soluble and pellet fractions [84]. As a consequence, CK activity in $\mathrm{AD}$ brain homogenates is decreased by $86 \%$, as shown by [alpha 32P] $8 \mathrm{~N} 3 \mathrm{ATP}$ incorporation into the enzyme, but the expression level of CK is decreased by less than $14 \%$ [84]. These findings can be explained by the fact that all CK isoforms possess a highly reactive cysteine residue that is specifically modified by sulfhydryl reagents or oxygen or peroxynitrite radicals [85]. Loss of BB-CK activity [82, 84, 86, 87], resulting from its oxidation [87], implies that the maintenance of a healthy cellular energy state is perturbed in the $\mathrm{AD}$ brain and that energy supply in glia cells, neurons, and synaptic elements is altered. This is corroborated by one study, where Alzheimer's patients were found to have reduced levels of brain PCr in early stages of the disease and decreased oxidative metabolism in later stages compared to healthy persons, indicating that the $\mathrm{AD}$ brain is under energetic stress [88].

\section{FORMATION AND PRESENCE OF FOCAL CREATINE DEPOSITS IN AD BRAIN}

The recent discovery of $\mathrm{Cr}$ deposits in the brains of transgenic APP mice by Fourier transform infrared microspectroscopy (FTIR) in frozen and desiccated brain slices [73] raises many questions concerning its role in $\mathrm{AD}$. At present, it is not known whether the creatine exists as precipitated microcrystals or as localized, sequestered pools in vivo. In this section, we speculate on some possible origins for these deposits. 
Cr is a very prominent compound in both muscle and brain, where total $\mathrm{Cr}$ ( $\mathrm{PCr}$ plus $\mathrm{Cr}$ ) may reach $50 \mathrm{mM}$ or $20 \mathrm{mM}$, respectively, the latter being strongly dependent on the region of the brain [36]. Intracellularly, under normal energetic conditions, $2 / 3$ of total $\mathrm{Cr}$ is in the form of energyrich $\mathrm{PCr}$ and $1 / 3$ in the form of Cr. During cellular energy stress, the $\mathrm{PCr} / \mathrm{Cr}$ ratio decreases. $\mathrm{Cr}$ is less insoluble than PCr, having a solubility limit of roughly $100 \mathrm{mM}$ in aqueous solution, depending on temperature and $\mathrm{pH}$. Thus, in glycolytic skeletal muscle that is highest in total $\mathrm{Cr}$, this solubility limit is nearly reached if all PCr was converted to Cr. In brain this is less likely, given the lower total Cr concentration. However, it is conceivable that upon massive destruction of neurons in $\mathrm{AD}$ accompanied by lysis and cell death, significant amounts of $\mathrm{Cr}$ are set free within the region of brain cell destruction. Thus, if concentrated, Cr might precipitate in the extracellular space of the brain, giving rise to focal deposits in vivo. However, no such neuronal loss is observed in the transgenic APP mice, nor are there obvious changes in cell morphology that would support such a hypothesis. In fact, the focal $\mathrm{Cr}$ deposits are seen in frozen brain sections that have to be desiccated before FTIR microspectroscopy measurements [73]. It is therefore not unreasonable to suppose that under in vivo (hydrated) conditions, the elevated Cr exists in solution, for example, inside intact cells or in vacuoles or other subcellular compartments, and that this Cr only solidifies into focal microcrystals when the tissue is dried.

Another explanation is based on a breakdown in the synthesis and/or neuronal uptake pathway of Cr. Some glial cells, especially oligodendrocytes, synthesize $\mathrm{Cr}$, which is then released to be taken up by neurons $[49,51]$. AD is accompanied by inflammation and an increase in the number of glial cells, providing an additional source of Cr. Neurons normally take up Cr from the extracellular space by CRT. If, however, neurons were energetically stressed, Cr uptake could be limited, because the uptake of Cr via CRT is accompanied by concomitant $\mathrm{Na}^{+}$and $\mathrm{Cl}^{-}$cotransport into the cell [54]. This $\mathrm{Na}^{+}$has to eventually be pumped out of the cell by the ATPdriven $\mathrm{Na}^{+} / \mathrm{K}^{+}$-ATPase that also uses a major part of cellular energy [30]. Thus, if Cr uptake into neurons was hampered, the net result would be a slow accumulation of $\mathrm{Cr}$ in the extracellular space.

A third possibility is that the oxidation of $\mathrm{BB}-\mathrm{CK}$ and uMtCK [85] limits the formation of PCr, which is in turn depleted to support ADP to ATP conversion, thus favoring the generation of excess $\mathrm{Cr}$.

Our recent data (see below) raise yet another possibility that uMtCK targeting to the mitochondria may be disrupted by a loss of APP function [89], which in turn would result in a decrease in synthesis of PCr and a concomitant accumulation of Cr within cells.

Since the microdeposits of Cr detected by FTIR microspectroscopy are found distributed focally across large regions of the hippocampus in the transgenic $\mathrm{AD}$ model mice [73], occasionally colocalized on the edges of $\mathrm{AD}$ plaques, it is likely that at least some of the $\mathrm{Cr}$ deposits are not intracellular, but rather in the extracellular space. They could be generated either by Cr leakage from dying cells or by impaired Cr trafficking between glia and neurons, as outlined above. However, irrespective of primary course, the factor triggering Cr deposits would be a disturbed energy charge of neurons under stress.

\section{INTERACTION AND COMPLEX FORMATION OF APP WITH MITOCHONDRIAL CREATINE KINASE}

Recent biochemical data from our laboratories provide a direct link between APP and uMtCK and shed new light on putative molecular mechanisms that lead to energetic abnormalities in AD brain (discussed above) [89]. Using a functional proteomic screen, in which APP interacting proteins were isolated based on their biochemical affinity and identified by peptide mass fingerprinting, we found that the short cytoplasmic tail of APP family proteins interacts with several different mitochondrial targeted proteins (see [89] and $\mathrm{Li}$ and Homayouni, unpublished observations). This interaction was of high affinity toward the preprotein forms, containing the $\mathrm{N}$-terminal signal sequence, of the mitochondrial proteins. Importantly, coexpression of APP C-terminal regions dramatically stabilized uMtCK in cultured cells. APP family proteins are type-I transmembrane glycoproteins that undergo sequential $\mathrm{N}$ - and O-linked glycosylation in the ER/Golgi pathway. Using co-immunoprecipitation assays, we found that uMtCK associated with the full-length but lower molecular weight APP proteins, suggesting that the interaction occurs prior to maturation of APP proteins. Immunohistochemical analysis indicated that APP and uMtCK colocalize in ER/Golgi and not in mitochondria of cultured primary neurons as well as in transiently transfected nonneuronal cells. These results raise the possibility that APP family proteins may function as cytoplasmic chaperone-like proteins to stabilize mitochondrial proteins such as uMtCK. Indeed, APP is induced and accumulates in the ER/Golgi of cultured cells after treatments that induce oxidative metabolic stress or ER stress via disruption of the ER folding machinery, thus affecting protein maturation and causing accumulation of unfolded proteins within the ER lumen $[90,91]$. In turn, some evidence indicates that APP induction can play a protective role against cell stress and axonal injury $[91,92]$.

Why then only mutations in APP, and not its other family members, have been linked to $\mathrm{AD}$ ? We propose that mutations in APP result in a dual attack on the mitochondria. First, these mutations enhance the generation of $\mathrm{A} \beta$ peptide [93], which were shown to be directly toxic to mitochondria through an interaction with ABAD [77]. Second, based on our recent data, we speculate that the loss of the normal function of APP in targeting of uMtCK, and perhaps other mitochondrial proteins to the mitochondria, would result in a further compromise of mitochondrial function in the affected neurons. This hypothesis is consistent with a stochastic model proposed by Clarke and colleagues [94], in which the mutated cell exists in an altered steady state and upon a random insult initiates a cascade of events resulting in cell death. It has been shown that mutations in APP 
increase the vulnerability of cells to oxidative stress [91, 95]. Although, these findings pertain to APP mutations, which are linked only to early-onset $\mathrm{AD}$, they suggest a more general mechanism for the pathogenesis of $\mathrm{AD}$ involving dysregulation of mitochondrial function $[65,96,97]$.

\section{NEUROPROTECTIVE EFFECTS OF CR SUPPLEMENTATION FOR NEURODEGENERATIVE DISEASES}

Over the past decade, the ergogenic benefits of synthetic $\mathrm{Cr}$ monohydrate have made it a popular dietary supplement, particularly among athletes [98]. The anabolic properties of $\mathrm{Cr}$ also offer hope for the treatment of diseases characterized by muscle weakness and atrophy, as well as for rehabilitation [99]. In serum-free cultured cells, Cr supplementation has been shown to protect rat hippocampal neurons against glutamate and $A \beta$ toxicity [100]. In an animal model of traumatic brain injury (TBI), it has been shown that Cr supplementation protects against neuropathology of TBI through mechanisms involving maintenance of mitochondrial bioenergetics and preservation of ATP levels [101]. This is due to the fact that newly entered $\mathrm{Cr}$ is phosphorylated inside the cell by the catalytic activity of $\mathrm{CK}$, leading to an increased PCr/ATP ratio and, thus, a higher energy charge in the cell. Brustovetsky et al demonstrated neuroprotective effects of PCr and Cr pretreatments against energetic deprivation caused by $3 \mathrm{NP}$ and glutamate excitotoxicity in cultured neurons [102]. There, surprisingly, extracellular PCr was more efficacious than $\mathrm{Cr}$. This could be explained by the fact that PCr is able to bind to and stabilize cell membranes [103].

Recent data using human fetal striatal and mesencephalic tissue identified $\mathrm{Cr}$ as a potent natural survival and neuroprotective factor for GABA-ergic neurons in a model for HD [104] and of dopaminergic neurons in a model for PD [105107]. Cr is also beneficial in animal models of cerebral ischemia [108-110] and spinal cord injury $[111,112]$. In the G93A transgenic mouse model for ALS, long-term Cr supplementation extends life span, significantly improves motor coordination [113], and reverts the cholinergic deficit in some forebrain areas at an intermediate stage of ALS [114]. In rat and mouse models of cerebral ischemia, oral $\mathrm{Cr}$ administration resulted in neuroprotection and remarkable reduction in ischemic brain infarction $[109,115]$. Postischemic caspase- 3 activation and cytochrome $c$ release were significantly reduced in creatine-treated mice. $\mathrm{Cr}$ administration buffered ischemia-mediated cerebral ATP depletion [115]. These authors suggest that a prophylactic $\mathrm{Cr}$ supplementation, similar to what is recommended for an agent such as aspirin, may be considered for patients in high stroke-risk categories.

Supplementation with $\mathrm{Cr}$ has been used as an adjuvant to a therapeutic scheme in numerous diseases associated with muscle and neuromuscular degeneration. To date, two clinical pilot trials to test the efficacy of $\mathrm{Cr}$ monohydrate in ALS have been completed without any measurable improvements in overall survival or in a composite measure of muscle strength [116, 117]. However, these pilot studies were powered only to detect a $30-50 \%$ or greater change in rate of decline of muscle strength. These trials raised new questions about the optimal dosage of $\mathrm{Cr}$ and its beneficial effects on muscle fatigue, a measure distinct from muscle strength. A large multicenter clinical trial is currently underway to further investigate the efficacy of Cr monohydrate in ALS and to address these unresolved issues. To date, evidence shows that Cr supplementation at 5-10 grams over a time period of 12 months has a good safety profile and is well tolerated by patients with ALS.

In a trial with HD patients, Cr supplementation lowered brain glutamate levels [118]. Very recent data from a randomized, double-blind, placebo-controlled study with 64 subjects with Huntington's disease (HD), $8 \mathrm{~g} /$ day of $\mathrm{Cr}$ administered for 16 weeks, show that $\mathrm{Cr}$ was well tolerated and safe. Serum and brain $\mathrm{Cr}$ concentrations increased in the $\mathrm{Cr}$-treated group and returned to baseline after washout. Intriguingly, serum 8-hydroxy-2'-deoxyguanosine (8OH2'dG) levels, an indicator of oxidative injury to DNA, were markedly elevated in $\mathrm{HD}$, but were reduced significantly by Cr treatment [119]. In patients with a novel cytochrome b mutation, Cr supplementation attenuated the production of free radicals and the paracrystalline intramitochondrial inclusions [120] brought about by crystallization of overexpressed MtCK inside mitochondria [121]. The rationale for the use of $\mathrm{Cr}$ along with available evidence from animal models and clinical trials for ALS and related neurodegenerative or neuromuscular diseases have been described in [122]. Thus, it is obvious that $\mathrm{Cr}$ as a simple nutritional supplement shows a great potential for neuroprotective effects in various neuromuscular and neurodegenerative diseases.

\section{RATIONALE FOR CREATINE SUPPLEMENTATION IN ALZHEIMER'S DISEASE}

Very recent data by Snyder et al show that $\mathrm{A} \beta$ addition to cortical neurons in cell cultures leads to internalization of NMDA-receptors with concomitant dephosphorylation of the NMDA receptor subunit NR2B at Tyr 1472 [123]. Since it has been shown earlier that $\mathrm{Cr}$ supplementation significantly protects neurons against $\mathrm{A} \beta$ neurotoxicity [100], it can be inferred that $\mathrm{Cr}$ may indirectly benefit $\mathrm{AD}$ patients by reducing the effects of $\mathrm{A} \beta$ toxicity and NMDA-receptor internalization. It may also alleviate the deterioration of glutamatergic neurotransmission and synaptic plasticity that are vital for learning and memory. For example, treatment of hippocampal neurons with $20 \mathrm{mM}$ Cr significantly increased both basal and activity dependent synaptogenesis [78]. In two studies, Cr supplementation has been shown to improve mental concentration [124], as well as memory and learning [125] in healthy human subjects. It is possible that this will also be true for early stage $\mathrm{AD}$ patients.

Given the evidence for metabolic dysfunction in AD, we hypothesize that $\mathrm{Cr}$ supplementation at an early time point of the disease might be useful in compensating for the disturbed energy metabolism in subjects with $\mathrm{AD}$ by replenishing the energy pools, activating mitochondrial respiration 
$[126,127]$ and protecting cells from apoptosis $[127,128]$. Although Cr cannot increase energy charge if CK is damaged, for example, by oxidative damage (see below), very early in the course of $\mathrm{AD}, \mathrm{CK}$ is still functioning to some extent, so it is reasonable to assume that $\mathrm{Cr}$ may be of benefit in those early phases. Further, CK isoenzymes are known to be prime targets of oxidative damage by free radicals [85-87] that are a hallmark of many neuromuscular and neurodegenerative diseases. The substrate $\mathrm{Cr}$, together with MgADP or MgATP, upon forming a transition state complex in the active site of $\mathrm{CK}$, has a protective effect against inactivation of CK isoenzymes by free radicals, such as oxygen radicals and peroxynitrite. In the case of $\mathrm{MtCK}, \mathrm{Cr}$ in the presence of nucleotide, additionally prevents the dissociation of native octameric MtCK into dimers [85]. Thus, an elevation of the intracellular concentration of $\mathrm{Cr}$ by $\mathrm{Cr}$ supplementation may confer additional protection to $\mathrm{CK}$ and concomitantly delay the free-radical induced inactivation of the CK system in brain that is seen in $\mathrm{AD}$ [87].

$\mathrm{Cr}$ might be expected to improve energetic conditions for all cells, as well as for "at risk neurons," in animal models of neurodegenerative diseases, providing temporary protection. Such protection would occur in a vital time period when cell fate is still in balance, or perhaps precritical, before secondary excitotoxicity might threaten weakened neurons. Such protection by $\mathrm{Cr}$, however, could only be expected if the CK system were not compromised in a significant way such that PCr would still be synthesized by CK. An additional mechanism by which Cr may exert neuroprotection, could be through activation of AMPK in the brain, in a manner similar to that recently shown in muscle cells [129]. Since AMPK is a cellular energy sensor and fuel gauge, this would lead to short-term and long-term compensatory reactions to help the cells recruit more energy sources, for example, by up-regulation of glucose transport and elevation of fatty acid oxidation [130].

Lastly, Cr may exert neuroprotection by reducing protein aggregation. For example, $\mathrm{Cr}$ was found to reduce transglutaminase-catalyzed protein aggregation, in vitro, [131] a process thought to be relevant for the formation of protein aggregate formation in several neurodegenerative diseases, including Alzheimer's, Parkinson's, and Huntington's disease.

Thus, one may postulate that $\mathrm{Cr}$ supplementation, in combination with other established clinical interventions, may be a very valuable adjunct therapy for patients at an early stage of the disease progression. However, additional studies are needed first to address the questions of where exactly the microcrystalline $\mathrm{Cr}$ deposits are located, for example, intraor extracellularly, and whether they are associated with specific structures of the brain. In addition, it would be important to be able to quantify $\mathrm{Cr}$ in these deposits. Since these focal $\mathrm{Cr}$ microdeposits are observed in the brain of transgenic APP mice, as well as AD patients [73], there is a valid concern that supplementation with extra $\mathrm{Cr}$ might exacerbate rather than ameliorate this situation. However, as reasoned above, Cr, if given at an early time point of disease, may prevent or delay the formation of $\mathrm{Cr}$ deposits that are a consequence of cellular pathology. In any case, Cr supplementation should be tested first on the transgenic APP mice in which the $\mathrm{Cr}$ deposits have been found. In the long term, if warranted by the outcome of such tests, further trials with $\mathrm{AD}$ patients could be performed. If successful, this cheap and safe intervention, involving as a nutritional supplement, may extend a huge socioeconomic benefit by improving the quality of life of $\mathrm{AD}$ patients and lowering exploding health care costs.

\section{ABBREVIATIONS}

$\begin{array}{ll}\text { 3NP } & \text { 3-nitropropionic acid } \\ \text { 8OH2'dG } & \text { 8-hydroxy-2'-deoxyguanosine } \\ \text { A } \beta & \text { amyloid beta peptide } \\ \text { ABAD } & \text { A } \beta \text {-binding alcoholdehydrogenase } \\ \text { AD } & \text { Alzheimer's disease } \\ \text { AGAT } & \text { L-arginine:glycine amidinotransferase } \\ \text { ALS } & \text { amyotrophic lateral sclerosis } \\ \text { AMPK } & \text { AMP-stimulated protein kinase } \\ \text { APP } & \text { amyloid precursor protein } \\ \text { BB-CK } & \text { cytosolic brain-type creatine kinase } \\ \text { CK } & \text { creatine kinase } \\ \text { CNS } & \text { central nervous system } \\ \text { Cr } & \text { creatine } \\ \text { CRT } & \text { Na }{ }^{+} \text {and Cl- dependent creatine transporter } \\ \text { FTIR } & \text { Fourier transform infrared } \\ \text { GAMT } & \text { S-adenosylmethionine:guanidinoacetate } \\ \text { HD } & \text { N-methyltransferase } \\ \text { MM-CK } & \text { Huntington's disease } \\ \text { PCr } & \text { cytosolic muscle-type creatinekinase } \\ \text { PD } & \text { phosphocreatine } \\ \text { PET } & \text { Parkinson's disease } \\ \text { sMtCK } & \text { positron emission tomography } \\ \text { SR } & \text { sarcomeric mitochondrial creatine kinase } \\ \text { TBI } & \text { sarcoplasmic reticulum } \\ \text { TCA } & \text { traumatic brain injury } \\ \text { UCH L-1 } & \text { tricarboxylic acid } \\ \text { uMtCK } & \text { ubiquitous mitochondrial creatine kinase } \\ & \end{array}$

\section{ACKNOWLEDGMENTS}

We kindly thank Tina Thurnherr for critical reading of the manuscript and all members of the Wallimann group for inspiring discussions. This work was supported by a Swiss National Foundation Grant No. 3100A0-102075 (US, TW), the Swiss Society for Research on Muscle Diseases (TW), the Swiss Cardiovascular Research and Training Network (TB), $\mathrm{NIH}$ subcontract LM007292-03 (RH), and the University of Tennessee, Center for Neurobiology of Brain Diseases ( $\mathrm{RH})$, as well as the Canadian Institutes of Health Research (KMG), the Manitoba Health Research Council (KMG), and NSERC, Canada (KMG). Funding support was also received from the Province of Manitoba, through the Manitoba Research and Innovation Fund. 


\section{REFERENCES}

[1] Ames A III. CNS energy metabolism as related to function. Brain Research. Brain Research Reviews. 2000;34(1-2):42-68.

[2] Saks V, Dzeja P, Schlattner U, Vendelin M, Terzic A, Wallimann T. Cardiac system bioenergetics: metabolic basis of Frank-Starling law. The Journal of Physiology. 2006;571(pt 2):253-273.

[3] Wallimann T, Turner DC, Eppenberger HM. Localization of creatine kinase isoenzymes in myofibrils. I. Chicken skeletal muscle. The Journal of Cell Biology. 1977;75:297-317.

[4] Korge P, Byrd SK. Functional coupling between sarcoplasmic reticulum-bound creatine kinase and $\mathrm{Ca}(2+)$-ATPase. European Journal of Biochemistry. 1993;213:973-980.

[5] Rossi AM, Eppenberger HM, Volpe P, Cotrufo R, Wallimann T. Muscle-type MM creatine kinase is specifically bound to sarcoplasmic reticulum and can support $\mathrm{Ca} 2+$ uptake and regulate local ATP/ADP ratios. The Journal of Biological Chemistry. 1990;265:5258-5266.

[6] Wallimann T, Schlosser T, Eppenberger HM. Function of Mline-bound creatine kinase as intramyofibrillar ATP regenerator at the receiving end of the phosphorylcreatine shuttle in muscle. The Journal of Biological Chemistry. 1984;259:52385246.

[7] Krause SM, Jacobus WE. Specific enhancement of the cardiac myofibrillar ATPase by bound creatine kinase. The Journal of Biological Chemistry. 1992;267:2480-2486.

[8] Ventura-Clapier R, Mekhfi H, Vassort G. Role of creatine kinase in force development in chemically skinned rat cardiac muscle. The Journal of General Physiology. 1987;89:815-837.

[9] Grosse R, Spitzer E, Kupriyanov VV, Saks VA, Repke KR. Coordinate interplay between $(\mathrm{Na}++\mathrm{K}+)$-ATPase and creatine phosphokinase optimizes $(\mathrm{Na}+/ \mathrm{K}+)$-antiport across the membrane of vesicles formed from the plasma membrane of cardiac muscle cell. Biochimica et Biophysica Acta. 1980;603:142-156.

[10] Booth RF, Clark JB. Studies on the mitochondrially bound form of rat brain creatine kinase. The Biochemical Journal. 1978;170:145-151.

[11] Schlattner U, Tokarska-Schlattner M, Wallimann T. Mitochondrial creatine kinase in human health and disease. Biochimica et Biophysica Acta. 2005.

[12] Kottke M, Adams V, Wallimann T, Nalam VK, Brdiczka D. Location and regulation of octameric mitochondrial creatine kinase in the contact sites. Biochimica et Biophysica Acta. 1991;1061:215-225.

[13] Kottke M, Adam V, Riesinger I, et al. Mitochondrial boundary membrane contact sites in brain: points of hexokinase and creatine kinase location, and control of $\mathrm{Ca} 2+$ transport. Biochimica et Biophysica Acta. 1988;935:87-102.

[14] Biermans W, Bakker A, Jacob W. Contact site between inner and outer mitochondrial membrane: a dynamic microcompartment for creatine kinase activity. Biochimica et Biophysica Acta. 1990;1018:225-228.

[15] Brdiczka D. Function of the outer mitochondrial compartment in regulation of energy metabolism. Biochimica et Biophysica Acta. 1994;1187:264-269.

[16] Jacobus WE. Respiratory control and the integration of heart high-energy phosphate metabolism by mitochondrial creatine kinase. Annual Review of Physiology. 1985;47:707-725.

[17] Eppenberger HM, Dawson DM, Kaplan NO. The comparative enzymology of creatine kinases. I. Isolation and characterization from chicken and rabbit tissues. The Journal of Biological Chemistry. 1967;242:204-209.
[18] Hemmer W, Zanolla E, Furter-Graves EM, Eppenberger HM, Wallimann T. Creatine kinase isoenzymes in chicken cerebellum: specific localization of brain-type creatine kinase in Bergmann glial cells and muscle-type creatine kinase in Purkinje neurons. The European Journal of Neuroscience. 1994;6:538-549.

[19] Lerner MH, Friedhoff AJ. Characterization of a brain particulate bound form of creatine kinase. Life Sciences. 1980;26 (23):1969-1976.

[20] Lim L, Hall C, Leung T, Mahadevan L, Whatley S. Neuronespecific enolase and creatine phosphokinase are protein components of rat brain synaptic plasma membranes. Journal of Neurochemistry. 1983;41:1177-1182.

[21] Oliet SH, Piet R, Poulain DA. Control of glutamate clearance and synaptic efficacy by glial coverage of neurons. Science. 2001;292:923-926.

[22] Ullian EM, Sapperstein SK, Christopherson KS, Barres BA. Control of synapse number by glia. Science. 2001;291:657661.

[23] Shen W, Willis D, Zhang Y, Schlattner U, Wallimann T, Molloy GR. Expression of creatine kinase isoenzyme genes during postnatal development of rat brain cerebellum: evidence for transcriptional regulation. The Biochemical Journal. 2002;367:369-380.

[24] Holtzman D, Tsuji M, Wallimann T, Hemmer W. Functional maturation of creatine kinase in rat brain. Developmental Neuroscience. 1993;15:261-270.

[25] Friedhoff AJ, Lerner MH. Creatine kinase isoenzyme associated with synaptosomal membrane and synaptic vesicles. Life Sciences. 1977;20(5):867-873.

[26] Xu CJ, Klunk WE, Kanfer JN, Xiong Q, Miller G, Pettegrew JW. Phosphocreatine dependent glutamate uptake by synaptic vesicles. A comparison with atpdependent glutamate uptake. The Journal of Biological Chemistry. 1996;271:1343513440.

[27] Barrantes FJ, Braceras A, Caldironi HA, et al. Isolation and characterization of acetylcholine receptor membraneassociated (nonreceptor v2-protein) and soluble electrocyte creatine kinases. The Journal of Biological Chemistry. 1985;260:3024-3034.

[28] Dunant Y, Loctin F, Marsal J, Muller D, Parducz A, Rabasseda $X$. Energy metabolism and quantal acetylcholine release: effects of botulinum toxin, 1-fluoro-2,4-dinitrobenzene, and diamide in the Torpedo electric organ. Journal of Neurochemistry. 1988;50:431-439.

[29] Brady ST, Lasek RJ. Nerve-specific enolase and creatine phosphokinase in axonal transport: soluble proteins and the axoplasmic matrix. Cell. 1981;23:515-523.

[30] Guerrero ML, Beron J, Spindler B, Groscurth P, Wallimann T, Verrey F. Metabolic support of $\mathrm{Na}+$ pump in apically permeabilized A6 kidney cell epithelia: role of creatine kinase. The American Journal of Physiology. 1997;272(2 pt 1):C697-C706.

[31] Abraham MR, Selivanov VA, Hodgson DM, et al. Coupling of cell energetics with membrane metabolic sensing. Integrative signaling through creatine kinase phosphotransfer disrupted by M-CK gene knock-out. The Journal of Biological Chemistry. 2002;277:24427-24434.

[32] Crawford RM, Ranki HJ, Botting CH, Budas GR, Jovanovic A. Creatine kinase is physically associated with the cardiac ATP-sensitive $\mathrm{K}+$ channel in vivo. The FASEB Journal. 2002;16:102-104.

[33] Jost CR, Van der Zee CE, In 't Zandt HJ, et al. Creatine kinase B-driven energy transfer in the brain is important for habituation and spatial learning behaviour, mossy fibre field 
size and determination of seizure susceptibility. The European Journal of Neuroscience. 2002;15:1692-1706.

[34] Streijger F, Oerlemans F, Ellenbroek BA, Jost CR, Wieringa B, Van der Zee CE. Structural and behavioural consequences of double deficiency for creatine kinases BCK and UbCKmit. Behavioural Brain Research. 2005;157:219-234.

[35] Friedman DL, Roberts R. Compartmentation of brain-type creatine kinase and ubiquitous mitochondrial creatine kinase in neurons: evidence for a creatine phosphate energy shuttle in adult rat brain. The Journal of Comparative Neurology. 1994;343:500-511.

[36] Wallimann T, Hemmer W. Creatine kinase in non-muscle tissues and cells. Molecular and Cellular Biochemistry. 1994;133134:193-220.

[37] Magistretti PJ, Pellerin L. Cellular mechanisms of brain energy metabolism and their relevance to functional brain imaging. Philosophical Transactions of the Royal Society of London. Series B, Biological Sciences. 1999;354:1155-1163.

[38] Mommaerts WF, Seraydarian K, Suh M, Kean CJ, Buller AJ. The conversion of some biochemical properties of mammalian skeletal muscles following cross-reinnervation. Experimental Neurology. 1977;55:637-653.

[39] Wallimann T, Wyss M, Brdiczka D, Nicolay K, Eppenberger HM. Intracellular compartmentation, structure and function of creatine kinase isoenzymes in tissues with high and fluctuating energy demands : the "phosphocreatine circuit" for cellular energy homeostasis. The Biochemical Journal. 1992;281(pt 1):21-40.

[40] Focant B, Watts DC. Properties and mechanism of action of creatine kinase from ox smooth muscle. The Biochemical Journal. 1973;135:265-276.

[41] Bessman SP, Carpenter CL. The creatine-creatine phosphate energy shuttle. Annual Review of Physiology. 1985;54:831862.

[42] Bessman SP, Geiger PJ. Transport of energy in muscle: the phosphorylcreatine shuttle. Science. 1981;211:448-452.

[43] Wallimann T, Eppenberger HM. Localization and function of M-line-bound creatine kinase. M-band model and creatine phosphate shuttle. Cell and Muscle Motility. 1985;6:239-285.

[44] Iyengar MR, Fluellen CE, Iyengar C. Creatine kinase from the bovine myometrium: purification and characterization. Journal of Muscle Research and Cell Motility. 1982;3:231-246.

[45] Levin RM, Longhurst PA, Levin SS. Creatine kinase activity of urinary bladder and skeletal muscle from control and streptozotocin-diabetic rats. Molecular and Cellular Biochemistry. 1990;97:153-159.

[46] Norwood WI, Ingwall JS, Norwood CR, Fossel TE. Developmental changes of creatine kinase metabolism in rat brain. The American Journal of Physiology. 1983;244:C205-C210.

[47] Hemmer W, Wallimann T. Functional aspects of creatine kinase in brain. Developmental Neuroscience. 1993;15:249-260.

[48] Ohtsuki S, Tachikawa M, Takanaga H, et al. The blood-brain barrier creatine transporter is a major pathway for supplying creatine to the brain. Journal of Cerebral Blood Flow and Metabolism. 2002;22(11):1327-1335.

[49] Tachikawa M, Fukaya M, Terasaki T, Ohtsuki S, Watanabe M. Distinct cellular expressions of creatine synthetic enzyme GAMT and creatine kinases uCK-Mi and CK-B suggest a novel neuron-glial relationship for brain energy homeostasis. The European Journal of Neuroscience. 2004;20:144-160.

[50] Braissant O, Gotoh T, Loup M, Mori M, Bachmann C. Larginine uptake, the citrulline-NO cycle and arginase II in the rat brain: an in situ hybridization study. Brain Research. Molecular Brain Research. 1999;70:231-241.
[51] Braissant O, Henry H, Villard AM, Speer O, Wallimann T, Bachmann C. Creatine synthesis and transport during rat embryogenesis: spatiotemporal expression of AGAT, GAMT and CT1. BMC Developmental Biology. 2005;5:9.

[52] Braissant O, Henry H, Loup M, Eilers B, Bachmann C. Endogenous synthesis and transport of creatine in the rat brain: an in situ hybridization study. Brain Research. Molecular Brain Research. 2001;86:193-201.

[53] Dringen R, Verleysdonk S, Hamprecht B, Willker W, Leibfritz $\mathrm{D}$, Brand A. Metabolism of glycine in primary astroglial cells: synthesis of creatine, serine, and glutathione. Journal of Neurochemistry. 1998;70:835-840.

[54] Straumann N, Wind A, Leuenberger T, Wallimann T. Effects of $\mathrm{N}$-linked glycosylation on the creatine transporter. The Biochemical Journal. 2005.

[55] deGrauw TJ, Cecil KM, Byars AW, Salomons GS, Ball WS, Jakobs C. The clinical syndrome of creatine transporter deficiency. Molecular and Cellular Biochemistry. 2003;244:45-48.

[56] Schulze A. Creatine Deficiency Syndromes. Molecular and Cellular Biochemistry. 2003;244:143-150.

[57] Beal MF. Energetics in the pathogenesis of neurodegenerative diseases. Trends in Neurosciences. 2000;23:298-304.

[58] Green DR, Reed JC. Mitochondria and Apoptosis. Science. 1998;281:1309-1312.

[59] Kasarskis EJ, Berryman S, Vanderleest JG, Schneider AR, McClain CJ. Nutritional status of patients with amyotrophic lateral sclerosis: relation to the proximity of death. The American Journal of Clinical Nutrition. 1996;63(1):130-137.

[60] Carri MT, Ferri A, Battistoni A, et al. Expression of a Cu, Zn superoxide dismutase typical of familial amyotrophic lateral sclerosis induces mitochondrial alteration and increase of cytosolic Ca2+ concentration in transfected neuroblastoma SH-SY5Y cells. FEBS Letters. 1997;414(2):365-368.

[61] Siklos L, Engelhardt J, Harati Y, Smith RG, Joo F, Appel SH. Ultrastructural evidence for altered calcium in motor nerve terminals in amyotropic lateral sclerosis. Annals of Neurology. 1996;39:203-216.

[62] Schubert D. Glucose metabolism and Alzheimer's disease. Ageing Research Reviews. 2005;4:240-257.

[63] Meier-Ruge W, Iwangoff P, Bertoni-Freddari C. What is primary and what secondary for amyloid deposition in Alzheimer's disease. Annals of the New York Academy of Sciences. 1994;719:230-237.

[64] Herholz K. PET studies in dementia. Annals of Nuclear Medicine. 2003;17:79-89.

[65] Castellani R, Hirai K, Aliev G, et al. Role of mitochondrial dysfunction in Alzheimer's disease. Journal of Neuroscience Research. 2002;70:357-360.

[66] Selkoe DJ. Translating cell biology into therapeutic advances in Alzheimer's disease. Nature. 1999;399:A23-A31.

[67] Small DH, McLean CA. Alzheimer's disease and the amyloid beta protein: what is the role of amyloid? Journal of Neurochemistry. 1999;73:443-449.

[68] Hoyer S. Causes and consequences of disturbances of cerebral glucose metabolism in sporadic Alzheimer disease: therapeutic implications. Advances in Experimental Medicine and Biology. 2004;541:135-152.

[69] Parker WD Jr. Cytochrome oxidase deficiency in Alzheimer's disease. Annals of the New York Academy of Sciences. 1991; 640:59-64.

[70] de la Monte SM, Luong T, Neely TR, Robinson D, Wands JR. Mitochondrial DNA damage as a mechanism of cell loss in Alzheimer's disease. Laboratory Investigation. 2000;80:13231335. 
[71] Maurer I, Zierz S, Moller HJ. A selective defect of cytochrome c oxidase is present in brain of Alzheimer disease patients. Neurobiology of Aging. 2000;21(3):455-462.

[72] Valla J, Berndt JD, Gonzalez-Lima F. Energy hypometabolism in posterior cingulate cortex of Alzheimer's patients: superficial laminar cytochrome oxidase associated with disease duration. The Journal of Neuroscience. 2001;21:4923-4930.

[73] Gallant M, Rak M, Szeghalmi A, et al. Elevated levels of creatine detected in APP transgenic mice and Alzeimer diseases brain tissue. The Journal of Biological Chemistry. 2005.

[74] Boveris A, Cadenas E. Mitochondrial production of hydrogen peroxide regulation by nitric oxide and the role of ubisemiquinone. IUBMB Life. 2000;50:245-250.

[75] Aksenov MY, Tucker HM, Nair P, et al. The expression of several mitochondrial and nuclear genes encoding the subunits of electron transport chain enzyme complexes, cytochromec oxidase, and NADH dehydrogenase, in different brain regions in Alzheimer's disease. Neurochemical Research. 1999;24(6):767-774.

[76] Cardoso SM, Proenca MT, Santos S, Santana I, Oliveira CR. Cytochrome c oxidase is decreased in Alzheimer's disease platelets. Neurobiology of Aging. 2004;25:105-110.

[77] Lustbader JW, Cirilli M, Lin C, et al. ABAD directly links Abeta to mitochondrial toxicity in Alzheimer's disease. Science. 2004;304:448-452.

[78] Li Z, Okamoto K, Hayashi Y, Sheng M. The importance of dendritic mitochondria in the morphogenesis and plasticity of spines and synapses. Cell. 2004;119:873-887.

[79] Pereira C, Agostinho P, Moreira PI, Cardoso SM, Oliveira CR. Alzheimer's disease associated neurotoxic mechanisms and neuroprotective strategies. Current Drug Targets. CNS and Neurological Disorders. 2005;4:383-403.

[80] Markesbery WR. Oxidative stress hypothesis in Alzheimer's disease. Free Radical Biology \& Medicine. 1997;23:134-147.

[81] Butterfield DA, Lauderback CM. Lipid peroxidation and protein oxidation in Alzheimer's disease brain: potential causes and consequences involving amyloid beta-peptide-associated free radical oxidative stress. Free Radical Biology \& Medicine. 2002;32:1050-1060.

[82] Smith CD, Carney JM, Starke-Reed PE, et al. Excess brain protein oxidation and enzyme dysfunction in normal aging and in Alzheimer disease. Proceedings of the National Academy of Sciences of the United States of America. 1991;88: 10540-10543.

[83] Castegna A, Aksenov M, Thongboonkerd V, et al. Proteomic identification of oxidatively modified proteins in Alzheimer's disease brain. Part II: dihydropyrimidinase-related protein 2, alpha-enolase and heat shock cognate 71 . Journal of Neurochemistry. 2002;82:1524-1532.

[84] David S, Shoemaker M, Haley BE. Abnormal properties of creatine kinase in Alzheimer's disease brain: correlation of reduced enzyme activity and active site photolabeling with aberrant cytosol-membrane partitioning. Brain Research. Molecular Brain Research. 1998;54:276-287.

[85] Stachowiak O, Dolder M, Wallimann T, Richter C. Mitochondrial creatine kinase is a prime target of peroxynitriteinduced modification and inactivation. The Journal of Biological Chemistry. 1998;273:16694-16699.

[86] Hensley K, Hall N, Subramaniam R, et al. Brain regional correspondence between Alzheimer's disease histopathology and biomarkers of protein oxidation. Journal of Neurochemistry. 1995;65:2146-2156.
[87] Aksenov M, Aksenova M, Butterfield DA, Markesbery WR. Oxidative modification of creatine kinase BB in Alzheimer's disease brain. Journal of Neurochemistry. 2000;74:2520-2527.

[88] Pettegrew JW, Panchalingam K, Klunk WE, McClure RJ, Muenz LR. Alterations of cerebral metabolism in probable Alzheimer's disease: a preliminary study. Neurobiology of Aging. 1994;15:117-132.

[89] Li X, Burklen T, Yuan X, et al. Stabilization of ubiquitous mitochondrial creatine kinase preprotein by APP family proteins. Molecular and Cellular Neurosciences. 2005.

[90] Gabuzda D, Busciglio J, Chen LB, Matsudaira P, Yankner BA. Inhibition of energy metabolism alters the processing of amyloid precursor protein and induces a potentially amyloidogenic derivative. The Journal of Biological Chemistry. 1994;269:13623-13628.

[91] Kogel D, Schomburg R, Schurmann T, et al. The amyloid precursor protein protects PC12 cells against endoplasmic reticulum stress-induced apoptosis. Journal of Neurochemistry. 2003;87:248-256.

[92] Xie Y, Yao Z, Chai H, Wong WM, Wu W. Potential roles of Alzheimer precursor protein A4 and beta-amyloid in survival and function of aged spinal motor neurons after axonal injury. Journal of Neuroscience Research. 2003;73:557-564.

[93] Citron M, Oltersdorf T, Haass C, et al. Mutation of the betaamyloid precursor protein in familial Alzheimer's disease increases beta-protein production. Nature. 1992;360:672-674.

[94] Clarke EE, Shearman MS. Quantitation of amyloid-beta peptides in biological milieu using a novel homogeneous timeresolved fluorescence (HTRF) assay. Journal of Neuroscience Methods. 2000;102:61-68.

[95] Eckert A, Steiner B, Marques C, et al. Elevated vulnerability to oxidative stress-induced cell death and activation of caspase3 by the Swedish amyloid precursor protein mutation. Journal of Neuroscience Research. 2001;64:183-192.

[96] Swerdlow RH, Khan SM. A "mitochondrial cascade hypothesis” for sporadic Alzheimer's disease. Medical Hypotheses. 2004;63:8-20.

[97] Eckert A, Keil U, Kressmann S, et al. Effects of EGb 761 Ginkgo biloba extract on mitochondrial function and oxidative stress. Pharmacopsychiatry. 2003;36(suppl 1):S15-S23.

[98] Bemben MG, Lamont HS. Creatine supplementation and exercise performance: recent findings. Sports Medicine. 2005;35(2):107-125.

[99] Hespel P, Op’t Eijnde B, Van Leemputte M, et al. Oral creatine supplementation facilitates the rehabilitation of disuse atrophy and alters the expression of muscle myogenic factors in humans. The Journal of Physiology. 2001;536(pt 2):625-633.

[100] Brewer GJ, Wallimann TW. Protective effect of the energy precursor creatine against toxicity of glutamate and betaamyloid in rat hippocampal neurons. Journal of Neurochemistry. 2000;74(5):1968-1978.

[101] Sullivan PG, Geiger JD, Mattson MP, Scheff SW. Dietary supplement creatine protects against traumatic brain injury. Annals of Neurology. 2000;48(5):723-729.

[102] Brustovetsky N, Brustovetsky T, Dubinsky JM. On the mechanisms of neuroprotection by creatine and phosphocreatine. Journal of Neurochemistry. 2001;76(2):425-434.

[103] Saks VA, Dzhaliashvili IV, Konorev EA. Molecular and cellular aspects of the cardioprotective mechanism of phosphocreatine. Biokhimiia. 1992;57(12):1763-1784.

[104] Andres RH, Ducray AD, Huber AW, et al. Effects of creatine treatment on survival and differentiation of GABA-ergic 
neurons in cultured striatal tissue. Journal of Neurochemistry. 2005;95(1):33-45.

[105] Andres RH, Ducray AD, Perez-Bouza A, et al. Creatine supplementation improves dopaminergic cell survival and protects against MPP+ toxicity in an organotypic tissue culture system. Cell Transplantation. 2005;14(8):537-550.

[106] Andres RH, Huber AW, Schlattner U, et al. Effects of creatine treatment on the survival of dopaminergic neurons in cultured fetal ventral mesencephalic tissue. Neuroscience. 2005;133(3):701-713.

[107] Ducray A, Kipfer S, Huber AW, et al. Creatine and neurotrophin- $4 / 5$ promote survival of nitric oxide synthaseexpressing interneurons in striatal cultures. Neuroscience Letters. 2005;395(1):57-62.

[108] Wilken B, Ramirez JM, Probst I, Richter DW, Hanefeld F. Anoxic ATP depletion in neonatal mice brainstem is prevented by creatine supplementation. Archives of Disease in Childhood. Fetal and Neonatal Edition. 2000;82(3):F224F227.

[109] Adcock KH, Nedelcu J, Loenneker T, Martin E, Wallimann T, Wagner BP. Neuroprotection of creatine supplementation in neonatal rats with transient cerebral hypoxia-ischemia. Developmental Neuroscience. 2002;24(5):382-388.

[110] Balestrino M, Lensman M, Parodi M, et al. Role of creatine and phosphocreatine in neuronal protection from anoxic and ischemic damage. Amino Acids. 2002;23(1-3):221-229.

[111] Rabchevsky AG, Sullivan PG, Fugaccia I, Scheff SW. Creatine diet supplement for spinal cord injury: influences on functional recovery and tissue sparing in rats. Journal of Neurotrauma. 2003;20(7):659-669.

[112] Hausmann ON, Fouad K, Wallimann T, Schwab ME. Protective effects of oral creatine supplementation on spinal cord injury in rats. The Journal of Spinal Cord Medicine. 2002;40 (9):449-456.

[113] Klivenyi P, Calingasan YN, Starkov A, et al. Neuroprotective mechanisms of creatine occur in the absence of mitochondrial creatine kinase. Neurobiology of Disease. 2004;15(3): 610-617.

[114] Pena-Altamira E, Crochemore C, Virgili M, Contestabile A. Neurochemical correlates of differential neuroprotection by long-term dietary creatine supplementation. Brain Research. 2005;1058(1-2):183-188.

[115] Zhu S, Li M, Figueroa BE, et al. Prophylactic creatine administration mediates neuroprotection in cerebral ischemia in mice. The Journal of Neuroscience. 2004;24(26):5909-5912.

[116] Shefner JM, Cudkowicz ME, Schoenfeld D, et al. A clinical trial of creatine in ALS. Neurology. 2004;63(9):1656-1661.

[117] Groeneveld GJ, Veldink JH, van der Tweel I, et al. A randomized sequential trial of creatine in amyotrophic lateral sclerosis. Annals of Neurology. 2003;53:437-445.

[118] Bender A, Auer DP, Merl T, et al. Creatine supplementation lowers brain glutamate levels in Huntington's disease. Journal of Neurology. 2005;252(1):36-41.

[119] Hersch SM, Gevorkian S, Marder K, et al. Creatine in Huntington disease is safe, tolerable, bioavailable in brain and reduces serum 8OH2'dG. Neurology. 2006;66(2):250-252.

[120] Tarnopolsky MA, Simon DK, Roy BD, et al. Attenuation of free radical production and paracrystalline inclusions by creatine supplementation in a patient with a novel cytochrome b mutation. Muscle \& Nerve. 2004;29(4):537-547.

[121] Stadhouders AM, Jap PH, Winkler HP, Eppenberger HM, Wallimann T. Mitochondrial creatine kinase: a major con- stituent of pathological inclusions seen in mitochondrial myopathies. Proceedings of the National Academy of Sciences of the United States of America. 1994;91(11):5089-5093.

[122] Ellis AC, Rosenfeld J. The role of creatine in the management of amyotrophic lateral sclerosis and other neurodegenerative disorders. CNS Drugs. 2004;18(14):967-980.

[123] Snyder EM, Nong Y, Almeida CG, et al. Regulation of NMDA receptor trafficking by amyloid-beta. Nature Neuroscience. 2005;8(8):1051-1058.

[124] Watanabe A, Kato N, Kato T. Effects of creatine on mental fatigue and cerebral hemoglobin oxygenation. Neuroscience Research. 2002;42(4):279-285.

[125] Rae C, Digney AL, McEwan SR, Bates TC. Oral creatine monohydrate supplementation improves brain performance: a double-blind, placebo controlled, cross-over trial. Proceedings. Biological Sciences. 2003;270(1529):2147-2150.

[126] Kay L, Nicolay K, Wieringa B, Saks V, Wallimann T. Direct evidence for the control of mitochondrial respiration by mitochondrial creatine kinase in oxidative muscle cells in situ. The Journal of Biological Chemistry. 2000;275(10):6937-6944.

[127] O'Gorman E, Beutner G, Dolder M, Koretsky AP, Brdiczka $\mathrm{D}$, Wallimann T. The role of creatine kinase in inhibition of mitochondrial permeability transition. FEBS Letters. 1997;414:253-257.

[128] Dolder M, Walzel B, Speer O, Schlattner U, Wallimann T. Inhibition of the mitochondrial permeability transition by creatine kinase substrates. Requirement for microcompartmentation. The Journal of Biological Chemistry. 2003;278(20): 17760-17766.

[129] Ceddia RB, Sweeney G. Creatine supplementation increases glucose oxidation and AMPK phosphorylation and reduces lactate production in L6 rat skeletal muscle cells. The Journal of Physiology. 2004;555(pt 2):409-421.

[130] Hardie DG, Sakamoto K. AMPK: a key sensor of fuel and energy status in skeletal muscle. Physiology (Bethesda). 2006;21:48-60.

[131] Burguera EF, Love BJ. Reduced transglutaminase-catalyzed protein aggregation is observed in the presence of creatine using sedimentation velocity. Analytical Biochemistry. 2005;350 (1):113-119. 


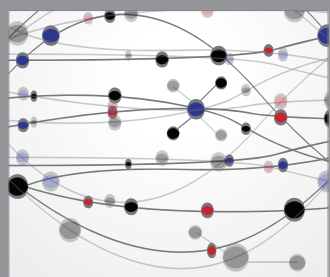

The Scientific World Journal
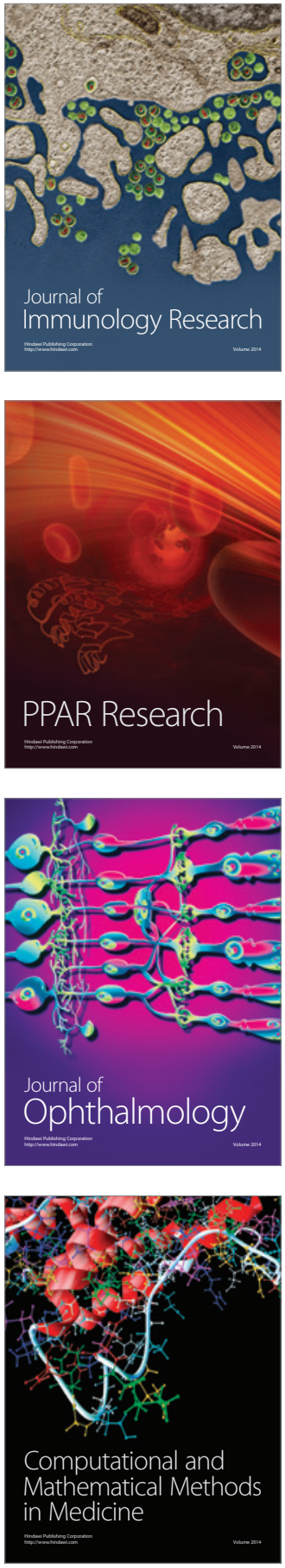

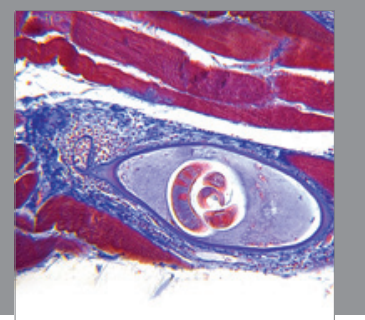

Gastroenterology

Research and Practice
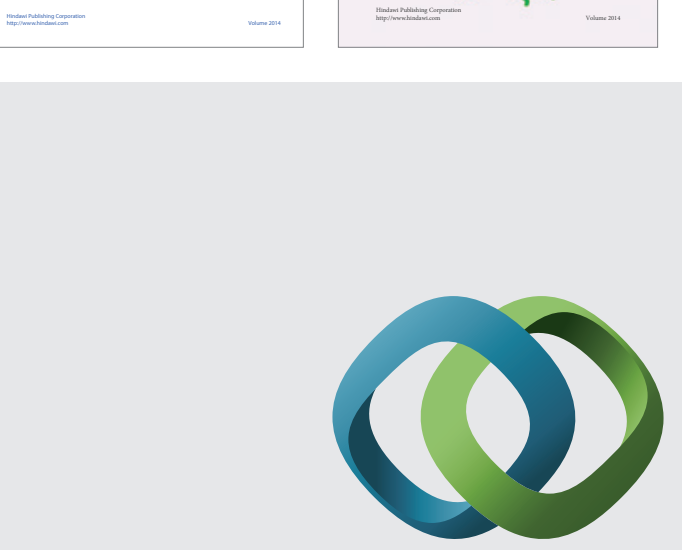

\section{Hindawi}

Submit your manuscripts at

http://www.hindawi.com
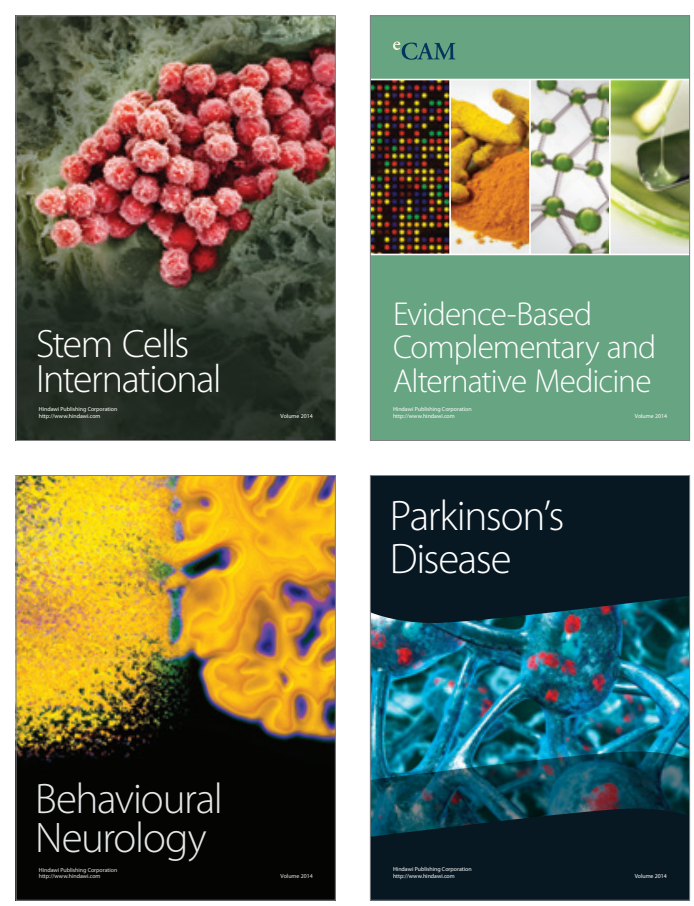

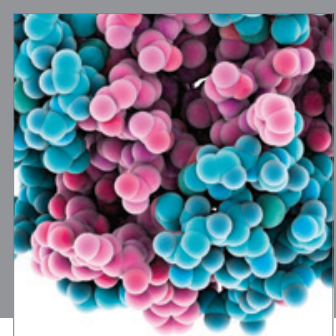

Journal of
Diabetes Research

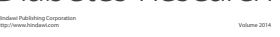

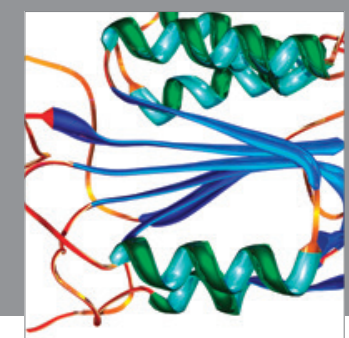

Disease Markers
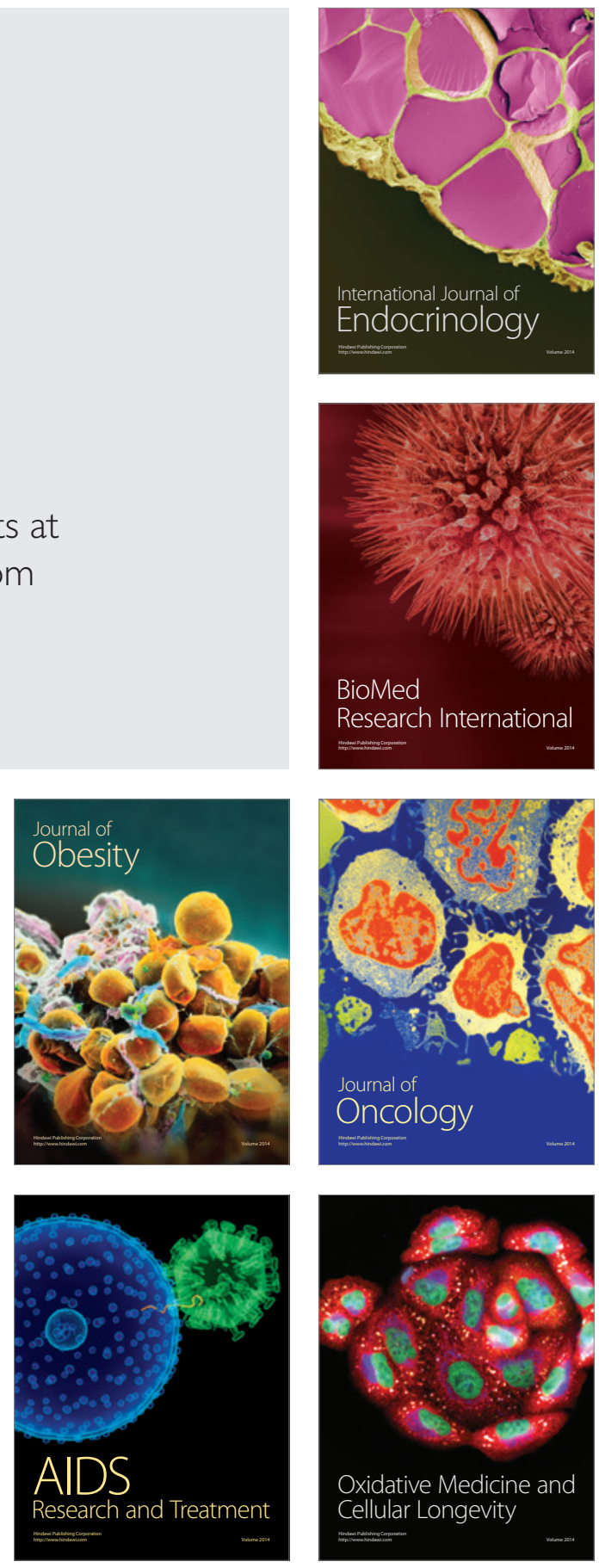